\title{
2. Some key themes
}

The adoption of money supply targets was announced publicly on 22 July 1976, although the Bank of England has claimed that it had in fact been privately following the money supply for two or three years before this. Money supply targets had repercussions on all areas of macroeconomic policy. Most obviously, as we saw in the previous section on 'Setting the agenda', there were implications for interest rates and exchange rates. Monetary targets required both that interest rates be readily adjusted to changing trends in money supply growth and that the exchange rate be allowed to float, in order to avoid possible inconsistencies between external and domestic objectives. But there were other problems. The various themes come back, at various points and in a number of guises, later in our story.

First, if monetary growth was fixed by a pre-ordained target, how could the Government alter demand in the economy and ensure full employment? The stock monetarist answer was that attempts to reduce unemployment beneath the so-called 'natural rate of unemployment', determined by structural characteristics of the labour market, would lead not to a stable high inflation rate, but to an ever-accelerating inflation rate and ultimately to hyper-inflation. I set out this view, which originated in Professor Milton Friedman's presidential address to the American Economic Association in 1967, in an article in The Times on 22 January 1975. In practice, the British Government effectively abandoned the objective of full employment in the mid-1970s, and employment considerations were not a major influence on macroeconomic policy at any point in the late 1970s or 1980s. (Of course, I am not denying that they were very important in the public debate on economic policy.)

An important corollary of the concept of a natural rate of unemployment needs to be spelt out. If a rate of unemployment maintained continuously beneath the natural rate leads to hyper-inflation, a rate of unemployment continuously above the natural rate leads to ever-falling inflation and eventually to price declines. (Technically, when unemployment is above the natural rate, the short-run inflation-unemployment trade-off improves indefinitely into the future, i.e. the short-run Phillips curve keeps on moving to the left. If unemployment is constant over a sequence of such short-runs, inflation must keep on falling.) I picked up this point in an article in The 
Spectator, entitled 'Following Friedman', on 28 May 1983, arguing that it pointed to extremely favourable prospects for growth and inflation in the mid-1980s.

The natural rate argument does not mean that the supporters of monetarism in the 1970s were indifferent to the suffering caused by large swings in economic activity. A central element in British monetarism was that large fluctuations in monetary growth should be avoided, since they were liable to cause extreme fluctuations in output and employment. In the mid-1970s the Manchester Inflation Workshop, led by Professors David Laidler and Michael Parkin, urged the case for 'gradualism', partly because they were worried that drastic monetary deceleration would cause an unnecessarily steep rise in unemployment. In fact, Professor Laidler was highly critical of the abruptness of the monetary slowdown between 1973 and 1974, and argued that it was the main cause of the intensity of the recession in early 1975 . I reported on 'gradualism' and the work of the Manchester Inflation Workshop in an article in The Times on 29 April 1975. (Note that the theme of gradualism had also been present in Friedman's own advocacy of stable monetary growth, although it had been not articulated in quite these terms. Friedman had grown up in the Great Depression of the 1930s.)

Finally, money supply targets altered the role of fiscal policy and questioned the validity of the Treasury's approach to economic management in the late 1960s and early 1970s. In this approach, the level of demand in the economy was adjusted by short-run changes in the fiscal position, usually at Budget time but sometimes at other points in the financial year. The direction and scale of such fiscal fine-tuning were determined by forecasts of future economic activity. These forecasts were derived from an elaborate econometric model containing many hundreds of equations. The practice of macroeconometric forecasting was relatively new in the mid-1970s, with the full-scale, computer-based Treasury model dating only from 1968.

Advocates of monetary targets regarded the Treasury's macroeconomic forecasts as of little help in taking the right decisions. This stemmed partly from a deep-seated scepticism that enough was known about the economy for the sort of enterprise on which the Treasury had embarked. But it also reflected the apparent inability of the Treasury model (and other macroeconometric models) to incorporate monetary influences successfully. In fact, the Treasury failed abjectly to foresee either the harshness of the 1975 recession or the increase in inflation to over 25 per cent. By contrast, the Manchester monetarists were roughly right in predicting both. My article in The Times of 28 August 1975, 'A lesson from the Treasury on how to be precisely wrong', concluded that, 'Unless and until conventional models incorporate monetary variables they will fail to capture some of the most important influences on the economy'. This theme re-surfaced in the late 
1980s, when, once again, Treasury forecasts became hopelessly wrong following a marked change in monetary growth. (See, in particular, 'The importance of money in macroeconomic forecasting - part 2', based on an article in The Spectator of 11 March 1989, on pp. 191-4.)

\section{Price Stability and the 'Natural' Level of Unemployment}

Reprinted from an article of the same name in The Times of 22 January 1975.

The article sets out Friedman's argument about the natural rate, with little additional comment. But it is worth mentioning that the then Economics Editor of The Times, Mr Peter Jay, had observed over a sequence of business cycles from the late 1950s, a continual deterioration in the unemploymentinflation trade-off. Friedman's analysis seemed to provide an explanation for this deterioration, as the gradual embedding of adverse inflation expectations would increase the unemployment cost required to achieve any given reduction in the inflation rate. (The original version of this article, which suffered badly from sub-editing, has been revised substantially.)

One sentence towards the end of the article is worth highlighting. This is the observation that, assuming no regime change which would banish inflationary expectations 'quickly and decisively', inflation could be cured only after 'four or five years' hard slog', with unemployment held above the natural rate for that length of time. This already hints at the time-scale of the Medium-Term Financial Strategy.

It is a commonplace that the Government faces a choice between inflation and employment objectives. Less unemployment, associated with policies which keep up demand in the economy, is also associated with rising wages and prices. It is perhaps less widely recognized that if the Government is too ambitious - if, for example, it aims to keep unemployment at extremely low levels - its options can deteriorate progressively. The price to be paid for driving unemployment down to unsustainable levels is not a once-for-all rise to a higher rate of inflation, but an ever-accelerating rate of inflation.

The dynamics of inflation may be unstable. Thus, it may be that if, in the first year, 3 per cent unemployment is accompanied by 5 per cent inflation, it will in the second year be accompanied by 5 per cent plus a little extra to make, say, 8 per cent, and in the third year, by 8 per cent plus a little extra to make 12 per cent, and so on. The process of degeneration is cumulative. 'Creeping inflation' (of 5 per cent a year or less) slides into 'strato-inflation' (20 per cent a year plus) and 'strato-inflation' culminates in 'hyper-inflation' (50 per cent a month or more). The theory that this is how the economy 
behaves, while a profoundly depressing one, is also rather suggestive. There is at least a case for saying that a move from creeping inflation to stratoinflation is precisely what has happened in Britain since the late 1960s. Serious commentators have even started to warn that, if nothing is done, Britain may end up with hyper-inflation.

The argument hinges on the idea of a 'natural level of unemployment'. This is the level which keeps supply and demand in the labour market balanced and at which unions, management and other labour market participants reach pay bargains similar to those prevailing in the past. If the level of unemployment drops beneath this rate, pay bargains tend to rise. The essence of the problem is that, once a particular rate of inflation has occurred and is expected to continue, the groups involved in collective bargaining make an allowance for it in their negotiations. This expectation of inflation is added to next year's pay settlements, pushing up the inflation rate; the higher inflation rate is then again embedded in pay bargainers' expectations and added to the following year's settlements, which pushes up the inflation rate further; and the yet higher inflation is again embedded in expectations and added to another year's settlements; and so on, until the economy suffers from hyper-inflation.

Economists used to call the old relationship between unemployment and wage increases the Phillips curve, after an economist at the London School of Economics who reported some of the historical statistics on the subject in a famous academic article. But, by recognizing the role of expectations, they now talk about a new relationship, 'the expectations-augmented Phillips curve'. It is explicitly understood that any unemployment rate less than the natural rate leads to ever-rising wage awards and ever-deteriorating inflation.

There are two sources of instability in this story. The first is the Government's commitment to a level of 'full employment' which is unsustainable because it forces unemployment beneath the natural rate. The second is the generation of inflationary expectations. Of course, if everyone were to believe that 5 per cent inflation this year will be succeeded by no inflation next, the progressive escalation to higher inflation rates could be avoided.

The Government can try to escape from this dilemma by restricting demand and permitting unemployment to increase. But here is the rub. Once inflationary expectations have contaminated the system, it is not sufficient to raise unemployment to the natural rate. To repeat, the natural rate is accompanied not by stable prices, but by stable pay increases and stable inflation. To reduce inflation, unemployment has to rise above the natural rate. Once an economy has experienced an inflation rate above 20 per cent, it probably has to undergo several years of deflationary agony, with very high unemployment, to restore inflation of 5 per cent or less. The effect of a few years of constantly rising inflation is to worsen the inflation-unemployment trade- 
off confronting the Government. A government which accords an excessive priority to high employment may, finally and ironically, have to 'trade' far more unemployment to keep inflation down than a government which is openly indifferent to the plight of the unemployed.

The theories of the natural rate of unemployment and the expectationsaugmented Phillips curve, which were put forward in American academic journals in 1967 and 1968, have some rather striking and obvious parallels with the real world of the early and mid-1970s. They were also at the centre of the discussions at an Institute of Economic Affairs (IEA) seminar last September, which have now been brought together in a new pamphlet. (Inflation: Causes, Consequences, Cures, published by the IEA in 1974.) The occasion was a field-day for Professor Milton Friedman, the most vigorous and well-known protagonist of these ideas.

Sceptics might reasonably ask: what is this 'natural rate of unemployment?'. It has a faintly mystical ring. What determines it? How is it to be measured? The discussion at the IEA seminar was largely concerned with these questions. It was argued that trade unions mattered because they distorted the working of the labour market and raised the natural rate. The potential relevance of the trade unions is easy enough to explain, at least in principle. Trade unions ask for higher wages than an unorganized labour force. In those parts of the economy where unionism is prevalent, the effect is artificially to raise the wage level. The inevitable by-product is higher unemployment. When governments try to counter the unemployment by stimulatory policy, it could be argued that the trade unions are the true source of the trouble and the real culprits for rising inflation.

Another possible determinant of the natural rate is a prices and incomes policy. Defenders of such a policy would argue that, both through its favourable effects on expectations and through direct compliance with the rules it lays down, it improves the inflation-unemployment trade-off. In the IEA discussion Professor Friedman showed himself extremely reluctant to acknowledge any importance in these qualifications. In his view, they were merely the institutional forms which the inflationary problem assumed. As Professor Friedman remarked, anything might be the first symptom of instability. In his words, 'It might on one occasion be the creation of a few trade unions. It might be a change in the terms of trade. It might be the loss of an export industry. There is a sense in which you can say in each of these cases that "the cause" of the inflation was a strong trade union or a trade deficit. But surely it is analytically cleaner to say that the fundamental cause of the inflation in all these cases is the adoption of a destabilizing monetary policy, namely, of an attempt to use a monetary weapon to fix something which it cannot fix.' 
After years of counter-inflation programmes, industrial relations Acts, special cases, 'norms' and 'ceilings', it is hard not to feel that Professor Friedman is right. If he is right, there are only two ways to cure the problem of inflation. The first is not 'two years' hard slog', but 'four or five years' hard slog', as unemployment held above the natural rate, combined with the cost-reducing effect of productivity increases, brings inflation down to more reasonable levels. The second is for the Government to make some gesture which would banish inflationary expectations quickly and decisively. This is the way hyper-inflations are eventually resolved, with the Government introducing a new currency and announcing draconian budgetary measures to make it credible. No such outcome is necessary or inevitable in this country, but it may help to maintain a sense of perspective to remember that reforms like these have taken place in both France and West Germany since the Second World War, and they don't seem to be doing so badly now.

\section{Gradual Monetary Deceleration - A Theme in British Monetarism}

From an article 'Making headway through the gentle therapy of British monetarism' in The Times, 29 April 1975.

This article is largely self-explanatory, but there are two points of particular interest. First, contrary to the reputation in public debate of monetarists as people who 'grow horns and breathe fire', the Manchester monetarists were acutely concerned in early 1974 that the slowdown in monetary growth was too sharp and too deflationary. Secondly, the article begins my practice of differentiating between British and American monetarism. The distinction is developed most fully in 'British and American monetarism compared', given at the annual Keynes seminar at the University of Kent in 1987 and reprinted here on pp. 209-34.

'Monetarism' has become a vogue word. It is frequently used in political debate, sometimes almost as a term of abuse. Indeed, it would seem not only to have lost the precise technical meaning it once possessed, but to have become a term without any exact meaning whatsoever.

In popular use the word normally has two connotations. According to the first, a monetarist believes that higher unemployment reduces wage demands and inflation; the second connotation is that savage cuts in public spending are required to help the Government balance its books and prevent excessive 'printing of money' if there is a deficit. There is a grain of truth in describing these attitudes as 'monetarist', but to think this is all that monetarism involves 
is grossly unfair. Perhaps the ease with which monetarism has been distorted reflects the American origins of the school of thought.

The home of modern monetarism is Chicago and its most well-known advocate is Professor Milton Friedman. There has been no strong British tradition to defend the purity of the term. However, monetarist economists are to be found in England and, contrary to a common misconception, they do not grow horns and breathe fire. The centre of monetarist studies is the University of Manchester, where a research project known as the Inflation Workshop has been under way for more than five years. It is under the direction of Professors David Laidler and Michael Parkin, and there are about 20 university lecturers and research assistants associated with it. They have built up a long and impressive list of publications.

At the outset it was not clear what tendency the Workshop's studies would take. The team's members were of all political persuasions, and of all the economic creeds and theologies which have been fashionable in recent years none was particularly dominant. Professor Parkin himself was a self-confessed Keynesian; he believed that changes in taxation and government spending were more effective ways of controlling the economy than changes in interest rates and the money supply. However, five years later all this has changed. The team's members are still of all political persuasions, but on economics they are united - or, at least, as united as economists are ever likely to be in their areas of professional competence. Money, they agree, matters; and if the outbreak of double-digit inflation is to be explained, the explanation is to be sought in governments' neglect of traditional canons of monetary and financial responsibility.

Because the root cause of inflation is regarded as lax monetary and fiscal policy, members of the Workshop favour, in present circumstances, the application of the brimstone and treacle of fiscal and monetary restraint. But this emphatically does not mean that they favour strict control of the money supply regardless of the consequences for demand and employment. Indeed, in early 1974, as the Healey money supply squeeze began, Professor Laidler was one of its most outspoken critics. The expansion of the money supply at rates of more than 25 per cent a year in 1972 and 1973 may have been responsible for the outbreak of excess demand pressures. But it would be folly, he argued, for the authorities to reduce the money supply growth rate to 10 per cent a year.

This rate of money supply deceleration would be too sharp. It would conflict with the system's inflationary expectations, cause a severe liquidity squeeze and result in a larger and more abrupt increase in unemployment than was necessary. In other words, Professor Laidler specifically rejected the idea that unemployment for its own sake was an objective of policy. Unemployment might be an unavoidable cost of overcoming inflation, but 
policy should be careful and considerate. As far as possible, it should minimize disruptive effects in the labour market.

One of the key words in the monetarist vocabulary at Manchester, as at Chicago, is 'gradualism'. The rise in the money supply should neutrally and steadily reflect the growth of the productive capacity of the economy, and should never alter abruptly. The justification for gradualism is that businesses and individuals form expectations about the economic outlook which depend crucially on current conditions. If government acts in such a way that current conditions are violently transformed within the space of a few months, the expectations created earlier will be inappropriate. Mistakes will tend to become more common and conflicts will arise from the mismatch between what people think they should have and what they can be allowed to have.

The most vivid and most discussed illustration of this general problem is in collective bargaining and in the process of wage formation as a whole. The starting-point of the Manchester economists is that inflation encourages people to expect continuing inflation. Pay settlements today will, therefore, tend to reflect yesterday's price increase. If price increases have been at an annual rate of 25 per cent and the government sits on the money supply so that it rises at only 10 per cent, trade unions will ask for 20 or 25 per cent pay rises while companies' bank deposits are rising much less. The two possible consequences are strikes and labour militancy if companies refuse to match the pay demands, or unemployment if wages are allowed to move out of line with companies' ability to pay. Neither of these consequences is desirable. It would be better to slow down the money supply slowly reducing growth to 15 or 20 per cent a year - so that expectations can be brought into a closer relation with the behaviour of demand.

The Manchester Workshop's analysis of expectations formation is probably its most distinctive contribution to economic debate. Some Chicago economists think of people forming expectations in a rational way, which implies a quick adjustment of attitudes to every twist and turn of policymaking. If inflation last year stood at 10 per cent, and the government continues to conduct macroeconomic policy in much the same way, people will assume - according to the rational expectation theorists - that inflation this year will also be 10 per cent. The Manchester economists regard the formation of expectations as more complicated. When inflation is running at 10 per cent they believe that people adjust to the existence of this inflation rate, but not completely. In their view, the typical reaction is to assume (from memories of previous non-inflationary years) that inflation will run at a particular fraction of 10 per cent - say 6 or 8 per cent. The analysis of the economy's behaviour and the development of theoretical models is made much more difficult by this pragmatic approach to the importance of expectations. Arguably, it is also made more realistic. 
Although expectations are emphasized as part of the inflationary process, other factors, particularly excess demand, are also regarded as vital. A belief in the effectiveness of market forces and a conviction that policies to restrain demand will eventually curb price and wage increases are two of the most typical attitudes of the Manchester economists. Monetarism as a political fashion may or may not be here to stay, but henceforward it need not be regarded as exclusively an American import.

\section{The Importance of Money in Macroeconomic Forecasting - Part 1}

From an article 'A lesson from the Treasury on how to be precisely wrong' in The Times, 28 August 1975.

The indictment of Treasury forecasting in this article is harsh. In effect, the article said that the resources and effort devoted to macroeconomic forecasting by the Treasury were a waste of public funds, essentially because its model failed to take proper account of the role of the money supply. A contrast is drawn between the Treasury's 'precisely wrong' forecasts and the Manchester monetarists' 'roughly right' forecasts. The Manchester monetarists reached their conclusions without the need for a large and expensive computer-based forecasting model. Like Mr Jay with his prediction of a 'boom that must go bust' in 1972, they were successful because they had a good basic understanding of the importance of money to macroeconomic outcomes.

Macroeconometric forecasting was given a subordinate position in Treasury policy-making when money supply targets were being followed in the early 1980s, but it became important again in the mid and late 1980s after the targets had been abandoned. Serious forecasting mistakes, similar to those in 1974 and 1975, were made in 1987 and 1988. As I argue in 'The importance of money in macroeconomic forecasting - part 2' (see below pp. 191-4) the forecasting errors in the Lawson boom had the same origin as the forecasting errors in the Barber boom, namely the failure of the Treasury model to attach sufficient importance to monetary variables.

One fortunate result of writing this article was that, as part of my research for it, I talked about the problems of economic model-building to several leading forecasters. These included Mr Terence (later Sir Terence) Burns, who prepared the London Business School's macroeconomic forecast jointly with Professor James (later Sir James) Ball. We met quite frequently for lunch in the next two or three years, as the London Business School's forecasting approach became, according to the media, steadily more monetarist. One of the topics we discussed most actively was how to specify 
fiscal policy when monetary targets were the centrepiece of macroeconomic management.

Economic forecasting has been one of the rare growth industries of these troubled times. Not only have companies and financial institutions become increasingly interested in its output, but government departments have also felt obliged to set up distinct forecasting functions. The Treasury, the powerhouse of British economic policy, has had a 'model' since the early 1960s. It has had a computer, capable of solving large simultaneous equation systems, since 1968. Assisted by this electronic gadgetry, the model has expanded at a far more spectacular rate than the economy it pretends to describe, and now consists of about 700 equations and identities.

But all is not well with the Treasury model. In the last five years the Government's handling of the economy has not been very happy and its public pronouncements on the future behaviour of major economic variables have usually been wrong. The latest example has been politically sensitive and, for that reason, more than usually newsworthy. To quote Mr Denis Healey, the Chancellor of the Exchequer, in his April Budget speech, 'The pressure of demand in the United Kingdom will continue easing and unemployment will continue to rise for the remainder of the year. I must warn the House that it could be touching a million by the end of the year.' But unemployment has misbehaved. It amounts to one-and-a-quarter million on some definitions and, on the central definition mentioned by Mr Healey, seasonally adjusted for the United Kingdom, it reached $1,008,800$ on 11 August, several months before schedule.

The abrupt and frightening change in labour market conditions has taken the Government by surprise, embarrassed ministers and caused some red faces among Treasury officials. The Government was nevertheless given advance warning by some independent forecasters. In early 1974 Professor David Laidler, then of the University of Manchester Inflation Project, foretold a sharp rise in unemployment in 18 months' time. His colleague, Professor Michael Parkin, was more definite. Unemployment, he said, would reach one million by July 1975 .

The Treasury's estimates - or, rather, 'guesstimates' - of future inflation rates have been even more lamentable, and the consequences have in some ways been just as disturbing. It has clearly been bewildered by the speed of pay and price increases since early 1974 . This has been the basic reason for runaway public spending and the present disarray in public sector finances. But the Manchester economists had said that 20 per cent inflation was inevitable some time before it happened. Professor Laidler's evidence to the House of Commons Expenditure Committee on 26 June 1974, was quite firm on this point. 'I would be surprised', he said, 'if the inflation rate 
stopped accelerating before mid- 1975 on the basis of past form. This means the rate of inflation will be over 20 per cent as things are going now. I wrote an article in March in which I said that we would be lucky to keep the rate below 20 per cent.'

The contrast between the Treasury and these independent outside observers should not be pressed to caricature. It is not a quarrel between devils and archangels. The Treasury is a large organization and it must be a struggle to reach a compromise between all the doctrinal positions represented. Some officials may well have agreed with the Manchester economists' warnings when they were given. But the fact remains that most officials did not, and that the Treasury as a whole was badly wrong. What is the matter with its forecasting procedures? Is there some fundamental weakness in its approach or is the work on the right lines but incompetently performed?

The Manchester economists have one great advantage over the official model. They believe that 'money matters', whereas most of the economists who developed the model regard money as an incidental extra to be ignored or remembered according to personal taste. It is possible to find forecasters in the Treasury who deny any connection between the 25 per cent rates of money supply growth in 1972 and 1973 and the 25 per cent rates of inflation found in 1974 and 1975. If one looked hard enough, it might even be possible to find forecasters who deny any connection between the Barber money supply explosion and the property boom or the growth of secondary banks.

It may be that such events are too close to the 'real world' to be of much interest to the Treasury. But official forecasters - and, indeed, private forecasters who also exclude monetary variables from their models - do have some good reasons for adopting their position. Their distrust of 'monetarism' arises from a belief that it has only one equation, that which links the money supply and the money national income. For Treasury purposes such a narrow approach is not much help. The Government needs to know what the prospects are for the major demand categories of consumption, investment and exports and for scores of minor sub-categories.

When monetary variables are incorporated in a detailed model they tend not to be as efficient for forecasting as traditional variables of the so-called 'Keynesian' kind. The relationships between interest rates, for example, and housebuilding or investment tend to be volatile and unreliable. They are not sufficiently stable for inclusion in a model which aims at exactitude and precision. The 'monetarists' do not dispute the variability of particular monetary relationships, although it does not worry them particularly. Whatever the difficulties of detail, they insist on the central connection between the money supply and money national income. 
Most 'monetarists' reject the practice of 'fine-tuning' the economy - that is, of trying to keep demand close to a hypothetical full employment level by marginal adjustments of government spending and taxation - as over-ambitious and basically misconceived. They are, on the whole, equally unenthusiastic about particular micro-interventions of the kind facilitated by detailed forecasting. These are some of the ways 'monetarism' coincides with a liberal approach to politics and economics generally.

It should also be said, at a more technical level, that a volatile relationship may still be a powerful one. No one in the Treasury believes - or at least, one hopes that no one in the Treasury believes - that interest rates and other financial factors do not affect housebuilding and investment. The fact that relationships jump up and down does not mean that the relationships are not there or that the money supply can be pumped up at unprecedented rates without influencing economic behaviour.

Moreover, there are plausible explanations for difficulty in accommodating monetary variables into forecasts. Equations are stable if the behaviour they describe is stable and if the institutional framework in which they operate varies little over time. But British monetary policy since the early 1960s has not created a continuous institutional framework. On the contrary, policy has been implemented by a succession of 'ceilings' on lending and directives on credit priorities. These adornments would inevitably have upset the data from which the equations were estimated, even if the underlying behaviour had been stable. If monetary institutions had been left alone, the responses of firms and individuals to financial signals might well have been regular and predictable.

In any case, to recall an old dictum, it is better to be roughly right than precisely wrong. Precise models without money seem to have been badly wrong in the last two or three years, while rough models with money seem to have been more or less right. The growing discontent with the full-blown several-hundred-equation system type of forecasting has encouraged interest in a less formal, but much more pragmatic and simple, approach. This relies on the use of certain statistical series as advance indicators of future economic developments.

The Central Statistical Office (CSO) has developed the technique and begun to publish the results in its monthly Economic Trends. These consist of four composite indices of indicators (two indices of leading indicators, one of coincident and one of lagging). If the index of leading indicators goes up it suggests that the economy is likely to revive in several months' time; if the index of lagging indicators increases it suggests that the economy was approaching a peak several months ago. If full-blown computer forecasting has pretensions to being a science, leading indicator forecasting is very definitely an art, above all, an art of selection and emphasis. It is essential to 
select those indicators which give a good guide to the way the economy is moving and to accord them the appropriate relative emphasis. Both selection and emphasis are improved if they spring from an integrated and complete theory of 'how the economy works'.

This is where 'monetarism' or, at any rate, a belief that monetary and financial variables are crucial to economic behaviour, scores well. The four components of the first CSO leading indicator index are the number of housing starts, the rate of interest on three-month bank bills, the corporate sector's acquisition of financial assets and the Financial Times ordinary share index. It is striking that all four are 'monetary', in the sense that they are profoundly influenced by monetary variables. The significance of monetary policy could hardly be more spectacularly confirmed. The same is true, though to a slightly lesser extent, of the second leading indicator index. This is influenced by four variables - the total increase in hire purchase debt, the number of insolvencies, wages per unit of output and new car registrations. Of these, only one (wages per unit of output) is not directly affected by credit and monetary conditions.

A 'Keynesian' forecaster would have great trouble fitting the success of these monetary variables into his world-view. To him the ups and downs in economic activity depend on a highly restricted range of 'exogenous variables', primarily world trade, public expenditure, tax rates and incomes policies. But the success of monetary variables in the leading indicator approach surely casts doubt on the validity of a several-hundred-equation computer approach which excludes them or refers to them only peripherally.

Interest in the leading indicator approach is likely to be furthered by a book, Cyclical Indicators for the Postwar British Economy, by Desmond O'Dea, published last month by the Cambridge University Press as an occasional paper for the National Institute of Economic and Social Research. It is particularly notable because it has come out under the aegis of the National Institute, a bastion of Keynesianism and the home of one of the biggest computer models in the United Kingdom. One finding of the study is that the level of share prices is one of the best signals of future economic development. A number of other indicators are awarded points according to their frequency and consistency in preceding changes in output and employment. The Financial Times dividend yields and ordinary share indices achieve some of the highest points totals. Other high scorers are the balance of payments, the price of raw materials purchased by industry and the Confederation of British Industry survey of business opinion.

It should surely be uncontroversial that the level of share prices depends very much on the conduct of monetary policy. The automatic reaction of any stock exchange in the world is to lower prices after an officially induced increase in interest rates. It is very difficult indeed to see how a conventional 
forecaster can both agree with the conclusions of leading indicator studies and believe that monetary policy is of little relevance to economic performance. However, the National Institute and the Treasury may not be especially concerned about the efficiency of monetary variables as predictive tools. The National Institute, which is considering the preparation of its own leading indicator index, seems untroubled by the inconsistency of publishing data on leading indicators and preparing standard forecasts in which these indicators play no role. Civil servants in the Treasury are most unlikely to start looking at the level of share prices to help them in the formulation of policy.

Unless and until conventional models incorporate monetary variables they will fail to capture some of the most important influences on the economy. Instead, the models will have to rely, as they do now, on assumptions, many of them highly political in nature, plucked out of thin air. The people who construct them will continue to see inflation as determined by erratic changes in the community's level of greed and envy (or 'union militancy') and output by violent and inexplicable swings in business optimism. In short, while Treasury forecasters deny that 'money matters', their forecasts will continue to have much in common with astrology. As laymen may have realized, both economic forecasting and astrology are based on a great deal of hunch, speculation and amateur psychology. 